the infected branches before serious injury was done, or by syringing the trees with a solution of whale oil soap,--or even common soft soap would do-just as the young lice are leaving the scales. It would be still better to have the solution hot. Whitman's Fountain Pump is admirable for making such applications.

Fig. I is slightly magnified; the others are largely magnified. The drawings were made from the objects by W. S. Holdsworth, a senior of the Michigan Agricultural College.

\title{
DESCRIPTION OF TWO NEW SPECIES OF CATOCALA.
}

BY A. R. GROTE, BUFFALO, N. Y.

Catocala Beaniana, n. s.

Intermediate between Briseis and Meskei. Fore wings paler than Briseis, with the t. p. line more dentate, and the brown subterminal shade paler; sub-reniform open. Hind wings red like Meskei, the middle black band broader, interrupted, transverse and not like Briseis, where it is still broader, continued and rounded, not so straight across the wing. Beneath much like Briseis, with the black bands broader and the white interspaces narrower than in Meskei. The subterminal white dentate shade on the primaries above more dentate than in Briseis. This species is similarly sized with Briseis, and is best described comparatively with that species and Meskci. Sent me by Mr. Thomas E. Bean, under the number 574, from Illinois.

Catocala Westcottii, n. s.

- $\hat{\sigma}$ q. Allied to anna, but smaller, with pale yellow hind wings and continuous bands, the median band angulated inferiorly and not so constricted superiorly as in that species. The primaries closely resemble anna in markings; the black outer shade of the t. a. line is quite similar and approaches anna and Westcottii to the group of nuptialis, abbreviatella and Whitneyi. Beneath the pale yellow outer interspace is narrower in Westcottii, and there is no basal black ray on secondaries, which show the 
black reniform mark on the disc as in anna. The mesial black band is subcontinuous and proportionately broader in Westcottii. Above the markings of fore wings are very similar in the two species; the tone is a little darker in Westiottii. The female expands 50 , the male $43 \mathrm{mil}$. I have the male from Illinois, Mr. Bean, number 577 ; the female from Wisconsin, Mr. O.S. Westcott, for whom I name the species.

\section{DESCRIPTION OF TWO NEW CALIFORNIAN BUTTERFLIES.}

BY THLODORE L. MEAD, NEW YORK.

Chionobas Trallda, n. sp.

MALE-Expanse $1_{10}^{\frac{8}{0}}$ to $2 \frac{3}{10}$ inches, average $2 \frac{2}{10}$ inches. Upper side of primaries fuscous, with velvety discal bar and a submarginal row of gray-ochraceous spots between the nervures. These spots are usually six in number, situated in the consecutive interspaces between the nervules, beginning with the last but one subcostal interspace, counting from the apex of the wing. The second of these spots always contains a black ocellus, pupilled with white. On the fifth interspace (last median) are usually faint indications of a fuscous dot in about one-third of the specimens examined; in one instance this dot is distinct and pupilled with white.

The ochraceous spots are not sharply defined unless very well developed; their length is not more than one-third that of the inner margin of the wing ; in breadth they sometimes occupy the whole interspace, leaving only a narrow border of fuscous on the nervule, while sometimes they are almost obsolete. The spots are always truncated on a line nearly parallel to the outer margin of the fore wing, thus leaving a fuscous border.

Costa mottled with gray and fuscous.

Secondaries gray-ochraceous with a fuscous border, usually with a pupilled ocellus in the second median interspace; this is occasionally obsolete. Nervures more or less distinctly fuscous.

Under side-Primaries gray-ochraceous, the pupilled spot or spots of the upper side shown more distinctly; the costa and apex mottled pale 